\title{
Anal Cancer pTis TNM Finding v6 and v7
}

National Cancer Institute

\section{Source}

National Cancer Institute. Anal Cancer pT is TNM Finding v6 and v7. NCI Thesaurus. Code C67553.

Anal cancer in situ. (from AJCC 6th and 7th Eds.) 